\title{
Strategi Pengelolaan Pusat Musik Liturgi Yogyakarta
}

\author{
Rolfi Junyanto Is Natonis \\ Program Pascasarjana Institut Seni Indonesia Yogyakarta \\ rolfy.natonis@gmail.com
}

\begin{abstract}
Abstrak
Dalam penelitian ini menggunakan metode deskriptif kualitatif. Langkah yang digunakan yaitu melakukan analisis data dan analisis SWOT. Hasil penelitian pertama, berdasarkan matrik IE dalam strategi PML Yogyakarta yang digunakan pada pengelolaan musik liturgi berada pada posisi $\mathrm{V}$ yaitu hold and maintaind, (pertahankan dan pelihara). Strategi umum yang dipakai adalah menjaga dan mempertahankan posisi internal yaitu memiliki jaringan kerja sama dengan komponis-komponis gereja lokal dalam menjalankan lokakarya mengenai musik liturgi yang selama ini sudah diraih. Kedua berdasarkan kuadran analisis SWOT pengelolaan PML Yogyakarta menunjukkan posisinya berada pada kuadran III. Stability, yaitu suatu lembaga menghadapi peluang pasar yang sangat besar, tetapi dilain pihak menghadapi beberapa kendala dalam internal seperti regenerasi yang belum memadai sehingga masih bergantung pada figur pendiri, keterbatasan tenaga pengelola baik dari segi kuantitas maupun kualitas, dan kegiatan lokakarya belum menjangkau semua budaya yang ada di nusantara. Ketiga berdasarkan analisis SWOT strategi umum yang diperoleh yaitu adalah penetrasi pasar dan pengembangan produk. Posisi tersebut mengarah pada menambah karya musik atau nyanyian nusantara dalam musik liturgi dan memberikan penataran dalam setiap tahun di gereja-gereja Katolik yang belum memahami tentang musik liturgi dalam inkulturasi dan memberikan pengetahuan dan penerjemah kepada pengelola sehingga cukup memadai.
\end{abstract}

Kata kunci: strategi pengelolaan, musik liturgi, swot, formulasi strategi

\begin{abstract}
In this research using qualitative descriptive method, The step used is doing data analysis and SWOT analysis. The first result of the research, based on the matrix of IE in PML Yogyakarta strategy used in the management of liturgical music is in position $V$ that is hold and maintaind. General strategy used is to maintain and maintain internal position that has a network of cooperation with composers the local church in running a workshop on liturgical music that has been achieved. The second is based on quadrant of SWOT analysis of PML Yogyakarta management showing its position is in quadrant III Stability, that is an institution facing huge market opportunity, but on the other hand facing some internal constraints such as regeneration that is not enough so that still depends on founder figure, both in terms of quantity and quality, and workshop activities have not yet reached all the cultures in the archipelago. Third based on the SWOT analysis the general strategies obtained are market penetration and product development. The position leads to; adding musical works or chants of the archipelago to liturgical music and giving up in every year catholic churches that have not understood the liturgical music in inculturation and providing knowledge and translators to the manager so that it is sufficient.
\end{abstract}

Keywords: management strategy, liturgical music, swot, strategy formulation 


\section{Pendahuluan}

Musik sangat penting dalam ibadah Gereja, sebab sebagian besar porsi ibadah Gereja memiliki unsur musik, baik vokal maupun instrumental. Makna musik dalam ibadah Gereja adalah pujian dan penyembahan. Hubungan musik dan liturgi bersifat harmonis, yaitu keseimbangan yang pas antara musik dan penghayatan iman menjadi tidak terpisahkan. Unsur musik dalam Gereja memiliki keterkaitan dengan Gereja, dalam hal pengembangan kehidupan spiritualitas, sumber daya, manajemen organisasi musik Gereja, mentalitas, keahlian, dan integritas keteladanan umat beriman yang harus senantiasa dipikirkan oleh Gereja sebagai manajemen organisasi.

Dengan begitu musik menjadi alat teologi dalam mendidik umat yang bertujuan mencerdaskan umat untuk berperilaku yang baik sesuai ajaran gereja, maka dari unsur-unsur tersebut, seni pertunjukan ibadah umat Kristiani harus berjalan secara sacral dan teratur untuk mencapai tujuan karena musik Gereja adalah dari Allah dan untuk dikembalikan kepada Allah maka kita harus melihat kembali apa yang patut kita kerjakan untuk musik Gereja, agar menempati porsi yang benar. Pertama, kita harus menyadari betapa besar dan kuatnya pengaruh organisasi musik Gereja terhadap banyak hal, terutama emosi manusia. Kedua, seni tidak dapat dicegah perkembangannya tetapi harus diikuti tanpa ikut terhanyut di dalamnya.

Hal ini kita harus memahami dan mengetahui tentang organisasi musik Gereja yang sudah diatur. Musik dan ibadah tidak dapat dipisahkan, sehingga untuk mencapai hasil yang prima dalam ibadah kita harus menggabungkan keduanya. Oleh karena itu, peranan organisasi musik Gereja adalah untuk menciptakan dan mengatur kesadaran akan suasana untuk ibadah, menghidupkan semangat manusia, menyatukan jemaat dalam suatu pengalaman ibadah bersama, dan menyatakan iman jemaat. Dengan kata lain, organisasi musik Gereja dapat menjembatani kegiatan beribadah dalam hubungan antara iman seseorang dengan perasaan dan sikap hidupnya.

Manajemen organisasi musik Gereja banyak hal yang diperhatikan secara baik dan profesional mulai dari urusan sederhana sampai dengan urusan ekonomi, sosial, dan teknologi. Di zaman sekarang, budaya musik Gereja semakin berkembang dibandingkan dengan masa-masa sebelumnya. Perkembangan ini selaras dengan perkembangan kebudayaan manusia. Selain itu, perkembangan musik Gereja sangat didukung oleh penemuan teknologi-teknologi baru. Di samping juga derasnya arus informasi dan komunikasi antarkelompok manusia di dunia ini semua kebudayaan di dunia sekarang ini saling memberikan pengaruh. Selain budaya musik Barat yang datang ke wilayah-wilayah dunia lainnya, di era globalisasi ini budaya musik Timur (oriental) juga mempengaruhi dan diadopsi oleh pelbagai kelompok manusia di dunia.

Manajemen musik Gereja sendiri memberikan peranan yang penting dalam sejarah. Di lain sisi juga memiliki pengaruh yang sangat kuat bagi manusia, karena musik dapat menjadi alat untuk merangsang emosi pendengarnya, memberikan inspirasi, mendorong ataupun sebaliknya dapat memberikan keseriusan dalam jiwa. Perkembangan budaya musik Gereja yang ada di era globalisasi ini bukan hanya terbatas kepada budaya musik populer saja, 
namun semua genre dan fungsi musik juga mengalami perkembangan dan pemanfaatan dalam masyarakat-masyarakat baru.

Konsili Vatikan II (1963-1965), arti Musik Gereja yang diartikan kiranya makin suci makin erat hubungannya dengan upacara ibadat. Berkat musik, ungkapan doa dijadikan lebih mendalam, rasa sehati umat semakin dipupuk, dan upacara-upacara suci diperkaya dengan rasa khidmat yang lebih besar. Di dalam penjelasan Konsili Vatikan II Musik Gereja ini dapat dibedakan menjadi dua jenis yaitu musik liturgi atau musik ibadah yang dimana Liturgi adalah puncak dan sumber hidup Kristiani. Sedangkan musik liturgi merupakan suatu bagian fungsional dalam liturgi (L112), karena bagian-bagian ibadat tertentu. Sejak awal perkembangannya, Gereja Katolik telah memaknai musik Gereja sebagai suatu bentuk komunikasi iman dalam perayaan liturgi. Hal ini selaras dengan pandangan dari Konsili Vatikan II, bahwa eksistensi musik Gereja bukan sebuah eksistensi material atau yang mencakup panca indera semata, melainkan suatu eksistensi yang bersifat spritual.

Ekspresi terhadap peranan musik Gereja dalam doa dan peribadatan Gereja, diungkapkan Santo Agustinus dalam sebuah pepatah Latin, yakni Bene cantat bis orat; yang berarti: "Bernyanyi dengan baik adalah berdoa dua kali". Ungkapan 'bernyanyi dengan baik' ini sesungguhnya menunjukkan suatu gradasi penghayatan dari sebuah aktus bernyanyi dalam ibadat Gereja. Artinya bernyanyi di dalam sebuah peribadatan, bukan sekedar melantunkan kata melalui nada-nada yang indah untuk menyenangkan hati, tetapi lebih dari itu, ialah untuk membangun sebuah komunikasi iman yang dihayati melalui keindahan nada, syair lagu, dan irama yang selaras dengan jiwa liturgi. Oleh karena itu, untuk menghayati musik Gereja sebagai sarana doa yang berdaya guna, dibutuhkan juga corak musik Gereja yang menunjang ibadat atau perayaan liturgi, yang mampu memperdalam sikap batin kepada Allah.

Prinsip Konsili Vatikan II yang menjadikan musik Gereja dinilai penting adalah relasi musik dengan aspek kebatinan dan kejiwaan manusia. Setiap manusia merasakan musik dengan melibatkan ekspresi batin dan jiwanya. Artinya meskipun musik Gereja memiliki kaidah-kaidah ilmiah - matematis, namun dalam pengapresiasiannya musik Gereja mengekspresikan batin dan jiwa manusia. Hal ini menegaskan bahwa dalam kehidupan religius dari berbagai agama, musik Gereja memainkan peranan penting dalam ritus-ritus keagamaan, entah lewat bunyi-bunyian instrumen musik maupun lewat nyanyian-nyanyian ritual. Dari fenomena ini, maka adalah penting untuk mengetahui makna dan apresiasi Gereja terhadap musik Gereja sebagai sebuah sarana peribadatan yang kini telah dikenal dengan sebutan 'musik liturgi'. Musik Gereja yang menyangkut pembaharuan liturgi, telah dipertimbangkan dengan seksama oleh Konsili Vatikan II. Konsili telah menjelaskan peranan musik Gereja di dalam upacara-upacara Ilahi dan telah mengeluarkan prinsip-prinsip dan undang-undang mengenai hal ini di dalam konstitusi tentang liturgi dan bahkan telah menyediakan satu bab khusus dari konstitusi itu untuk membahas persoalan musik Gereja.

Di dalam liturgi, umat beriman menduduki peranan utama. Oleh sebab itu, musik Gereja hendaknya mengabdi pada kepentingan umat dan senantiasa mendorong partisipasi umat secara aktif dalam perayaan liturgi. Hal ini tidak berarti bahwa musik Gereja semakin berkurang sehubungan dengan sifat massal dari umat, sebaliknya harus semakin bermutu dan berkesan. Oleh karena itu potensi di kalangan umat perlu dilibatkan, dan inisiatif yang sudah ada perlu diperhatikan. 
Sejak Konsili Vatikan II dengan lantang dalam gereja Katolik bergema memberikan anjuran agar gereja membuka diri dan menerima unsur-unsur kebudayaan setempat sejauh unsur-unsur kebudayaan itu tidak secara prinsip bertolak belakang dengan ajaran agama Katolik. Hal inilah yang membuat musik gereja dalam umat Kristiani dari waktu ke waktu semakin lama semakin berkembang fungsi dan strukturnya. Salah satu pihak yang terus menerus mengusahakan hal tersebut ialah Pusat Musik Liturgi (PML) Yogyakarta. PML merupakan salah satu lembaga musik di Indonesia yang mengabdi untuk mengembangkan musik liturgi Gerejawi. Pusat Musik Liturgi didirikan pada tanggal 11 Juli 1971 (tepat pada peringatan Santo Beneddictus). Pendirian PML bermula dari kecintaan dan ketertarikan Prier dan Widyawan terhadap musik liturgi (terutama musik inkulturasi) dan budaya Indonesia.

\section{Tinjauan Pustaka}

Giandar (2013) dalam Jurnal Manajemen Administrasi dan Fungsi Organisasi Musik Gerja di Ungaran Kabupaten Semarang, mengkaji tentang fungsi organisasi musik gereja berbeda dari kebanyakan organisasi musik gereja yang ada di wilayah Ungaran. Perbedaan tersebut terletak pada tata cara beribadah (musik) yang tergolong tepat dan mampu mengatur sistem di dalam gereja oleh umat gereja. Hal inilah yang menjadikan manajemen administrasi musik gereja yang baik menjadikan organisasi dalam musik gereja bertahan sampai sekarang. Masalah yang muncul dari penelitian ini adalah bagaimana manajemen administrasi dan fungsi organisasi musik gereja di Ungaran. Data-data yang dikumpulkan atau digunakan dalam penelitian ini adalah observasi, wawancara, dan dokumentasi. Teknik analisis penelitian ini terbagi dalam tiga tahap yaitu reduksi data, penyajian data, dan menarik kesimpulan. Hasil yang ditemukan dalam penulisan ini adalah manajemen administrasi Musik Gereja; meliputi organisasi yang terstruktur dengan baik, manajemen masih banyak ditemukan kekurangan dan kelemahan di setiap unsur administrasi, kepemimpinan, kepegawaian, keuangan dalam bentuk pembukuan, penganggaran, dan pemeriksaan, perlengkapan tercatat dalam daftar inventaris, pekerjaan kantor. Administrasi keorganisasian di Ungaran belum terstruktur dengan baik, dan manajemen yang kurang profesional karena manajer dan petugas administrasi masih ditangani oleh satu orang. Fungsi dari organisasi tersebut belum tercapai pada tujuannya. Dikarenakan pada administrasi yang masih banyak ditemukan kekurangan dan kelemahannya dari berbagai unsur administrasi. Diharapkan pengelola gereja mampu membenahi manajemen sekarang ini agar tetap eksis.

Untung (2010) dalam Jurnal Strategi Pengelolaan Musik Pusat Kebudayaan Belanda Erasmus Huis di Indonesia. Mengkaji tentang 4 aspek fungsional manajemen yaitu 1. Manajemen produksi dimana menyangkut perencanaan hingga operasional kegiatan dalam EH; 2. Pemasaran yang merupakan suatu kegiatan terencana dalam EH; 3. Sumber Daya Manusia menyangkut personalia yang merencanakan hingga menjalankan kegiatan di dalam $\mathrm{EH}$; serta 4. Keuangan pengelolaan yang baik.

Data-data yang dikumpulkan yaitu studi pustaka, observasi, wawancara, dan studi dokumentasi. Hasil yang didapat dalam penulisan ini yaitu dalam melaksanakam kegiatan musiknya, EH menjalankan kegitannya dengan melibatkan pihak seperti lembaga penerima. 
Untuk itu EH menerapkan mekanisme kerja sama yang transparan dan memiliki panduan yang sama untuk melakukan tugas masing-masing. Hal inilah yang menjawab bahwa untuk menjalankan cara manajemen kegiatan tersebut perlu adanya hubungan sosial, yaitu ditunjukkan adanya kerja sama EH dengan mitra.

Secara tidak langsung, setiap strategi pengelolaan yang dilakukan oleh PML Yogyakarta berkaitan dengan tingkat manajemen organisasi yang dilakukan dalam pengelolaan, seperti pengembangan manajemen strategi karena di dalam PML Yogyakarta tersebut masih terbilang kurangnya regenerasi yang belum memadai sehingga masih bergantung pada figur pendiri dan keterbatasan tenaga pengelola, baik dari segi kuantitas maupun kualitas. Di dalam PML Yogyakarta adanya manajemen sumber daya manusia ini untuk mengembangkan efektivitas lembaga dan tujuannya untuk mengakui bahwa keberadaan manajemen sumber daya manusia sangat membantu efektivitas kinerja lembaga.

Tujuan manajemen organisasi terdiri atas survival yaitu mampu bertahan dalam menghadapi tantangan yang bersifat eksternal dan internal, profit dan efficiency yaitu maksimalisasi pengelolaan dengan tetap memperhatikan efisiensi organisasi di segala bidang, dengan demikian pencapaian dalam pengeloaan PML Yogyakarta mampu memperhatikan efektivitas organisasi.

\section{Landasan Teori}

Proses manajemen strategi terdiri atas 3 tahapan (Fred R. David, 2016) yaitu sebagai berikut:

a. Perumusan Manajemen dan Organisasi

Perumusan manajemen mencakup pengembangan visi dan misi, identifikasi peluang dan ancaman eksternal suatu organisasi, kesadaran akan kekuatan dan kelemahan internal, penetapan tujuan jangka panjang, pencarian strategi-strategi alternatif, dan pemilihan strategi tertentu untuk mencapai tujuan. Keputusan perumusan strategi mendorong suatu organisasi untuk komit pada produk, pasar, sumber daya, dan teknologi spesifik selama kurun waktu yang lama. Perumusan strategi menentukan unggulan kompetitif jangka panjang.

b. Penerapan Manajemen

Penerapan manajemen mengharuskan organisasi untuk menetapkan tujuan tahunan, membuat kebijakan, memotivasi kelompok, dan mengalokasikan sumber daya, sehingga strategi-strategi yang telah dirumuskan dapat dijalankan. Penerapan strategi mencakup 15 pengembangan budaya yang suportif pada strategi, penciptaan struktur organisasi yang efektif, pengerahan ulang upaya-upaya pemasaran, penyiapan anggaran, pengembangan serta pemanfaatan sistem informasi, dan pengaitan kompensasi kelompok dengan kinerja organisasi. Penerapan strategi biasa disebut sebagai "tahap aksi" dari manajemen strategi. Penerapan strategi yang berhasil bergantung pada kemampuan manajer untuk memotivasi karyawan, yang lebih merupakan seni daripada pengetahuan. Strategi yang dirumuskan bila tidak diterapkan dengan baik maka strategi tersebut tidak ada gunanya.

c. Penilaian Manajemen

Penilaian manajemen adalah tahap terakhir dalam manajemen strategi. Manajer harus tahu kapan ketika strategi tertentu tidak berjalan dengan baik; penilaian atau evaluasi strategi merupakan cara utama untuk memperoleh informasi semacam ini. Semua strategi terbuka untuk dimodifikasi di masa yang akan datang karena berbagai faktor eksternal dan internal 
terus menerus berubah. Tiga aktivitas paling mendasar dari penilaian strategi adalah sebagai berikut:

- Peninjauan ulang faktor-faktor eksternal dan internal yang menjadi landasan bagi strategi saat ini.

- Pengukuran kinerja.

- Pengambilan langkah korektif. Penilaian strategi diperlukan karena apa yang berhasil saat ini tidak selalu berhasil nanti.

Kemudian dilanjutkan dengan merumuskan penulisan penelitian ini dengan menggunakan Analisis SWOT. Penjelasannya sebagai berikut:

\section{Alat Analisis SWOT}

Analisis SWOT atau analisis situasi merupakan awal proses perumusan strategi. Analisis ini mengharuskan para manajer strategis untuk menemukan kesesuaian strategis antara peluang-peluang eksternal dan kekuatan-kekuatan internal, di samping memperhatikan ancaman-ancaman eksternal dan kelemahan-kelemahan internal. SWOT adalah akronim untuk Strengths, Weaknesses, Opportunities, dan Threats dari organisasi yang semuanya merupakan faktor-faktor strategis. Analisis SWOT harus mengidentifikasi kompetensi langka perusahaan, yaitu keahlian tertentu dan sumber-sumber yang dimiliki oleh sebuah perusahaan dan cara unggul yang mereka gunakan. Penggunaan kompetensi langka perusahaan secara tepat akan memberikan keunggulan kompetitif yang berkelanjutan. Di dalam analisis SWOT menggunakan analisis lingkungan internal dan eksternal. Berikut penjelasannya.

a. Analisis Lingkungan Internal

Analisis internal adalah analisis terhadap aktivitas perusahaan, hal ini berkaitan dengan identifikasi kekuatan dan kelemahan. Kekuatan dan kelemahan internal dapat muncul dari aktivitas manajemen, pemasaran, keuangan, produksi, penelitian dan pengembangan, dan sistem informasi (Fred R. David: 2016).

b. Analisis Lingkungan Eksternal

Analisis lingkungan eksternal adalah pengungkapan peluang dan ancaman utama yang dihadapi perusahaan sehingga perusahaan akan bisa mendapatkan keuntungan dari peluang yang ada dan sebaliknya, ancaman yang muncul dari lingkungan perusahaan akan berusaha untuk menghindarinya. Peluang dan ancaman eksternal mengacu pada ekonomi, sosial budaya, demografi, lingkungan, politik, hukum, pemerintah, teknologi, serta tren kompetisi yang secara signifikan dapat menguntungkan atau membahayakan organisasi di masa depan (Fred R. David : 2016).

Rangkuti (2010) menjelaskan bahwa matriks SWOT dapat menggambarkan secara jelas bagaimana peluang dan ancaman eksternal yang dihadapi perusahaan dapat disesuaikan dengan kekuatan dan kelemahan yang dimilikinya.

Berikut ini penjelasan empat set kemungkinan alternatif strategi:

1. Strategi SO yaitu strategi yang menggunakan kekuatan internal perusahaan untuk memanfaatkan peluang eksternal.

2. Strategi WO yaitu strategi yang bertujuan untuk memperbaiki kelemahan internal dengan memanfaatkan peluang eksternal. 
3. Strategi ST yaitu strategi yang menggunakan kekuatan internal perusahaan untuk menghindari atau mengurangi pengaruh dari ancaman eksternal.

4. Strategi WT yaitu strategi yang menggunakan kegiatan bersifat difensif yang diarahkan pada pengurangan kelemahan internal dan menghindari ancaman eksternal.

Pada konsep yang digunakan dalam penelitian ini merupakan konsep Manajemen Strategi dengan menggunakan alat analisis SWOT dalam menganalisis strategi yang digunakan oleh PML Yogyakarta dapat diperoleh kesimpulan terkait kekuatan dan kelemahan serta peluang dan ancaman dalam PML Yogyakarta tersebut. Dari data yang telah didapatkan melalui analisis SWOT, kemudian dapat disimpulkan dan diambil keputusan untuk formulasi strategi yang diterapkan pada PML Yogyakarta tersebut. Formulasi di sini yang dimaksudkan berupa tahapan dari proses manajemen strategi yang terdiri dari tiga tahap, yakni: formulasi strategi, implementasi strategi, dan evaluasi strategi. Formulasi strategi termasuk mengembangkan visi dan misi, mengidentifikasi peluang dan ancaman eksternal perusahan, menentukan kekuatan dan kelemahan internal, menetapkan tujuan jangka panjang, merumuskan alternatif strategi, dan memilih strategi tertentu yang akan dilaksanakan.

\section{Metode Penelitian}

Penelitian ini dilakukan dengan metode kualitatif dengan menggunakan pendekatan studi kasus untuk mengeksplorasi dan memahami makna yang oleh sejumlah individu atau sekelompok orang dianggap berasal dari masalah sosial atau kemanusiaan (Cresswel, 2016: 4-5).

Makna yang dipahami pada penelitian ini adalah pemahaman terhadap pengelolaan PML. Proses penelitian ini melibatkan upaya-upaya penting, seperti mengajukan pertanyaanpertanyaan dan prosedur-prosedur pengumpulan data yang spesifik dari para partisipan, menganalisis data secara induktif mulai dari tema-tema yang khusus ke tema-tema yang umun serta menafsirkan data. Pendekatan yang digunakan adalah analisis SWOT.

\section{Hasil dan Pembahasan}

Pusat Musik Liturgi (PML) didirikan untuk mengabdi pada perkembangan musik di Indonesia pada umumnya, dan khususnya pada musik liturgi terutama dalam rangka inkulturasi atau "pengungkapan perayaan liturgi dalam tata cara dan susunan yang selaras dengan cita rasa budaya umat yang beribadat".

Visi - Misi tersebut didasari oleh hasil Konsili Vatikan II yang menghendaki agar "Gereja memelihara dan memajukan kekayaan yang menghiasi jiwa pelbagai suku dan bangsa. Apa saja dalam adat kebiasaan para bangsa, yang tidak secara mutlak terikat pada takhayul atau ajaran sesat, oleh Gereja dipertimbangkan dengan murah hati, dan bila mungkin dipeliharanya dalam keadaan baik dan utuh. Bahkan ada kalanya Gereja menampungnya dalam liturgi sendiri, asal saja selaras dengan hakikat semangat liturgi yang sejati dan asli” 


\section{Variabel IE}

Internal

Kekuatan:

- Merupakan lembaga yang telah diakui oleh Gereja Katolik Indonesia di bawah naungan KWI (Konferensi Waligereja Indonesia).

- Memiliki kemandirian dalam berkarya baik hak cipta dan hak atas kekayaan intelektual.

- Memiliki tenaga pengelola yang profesional.

- Mengembangkan musik tradisional ke dalam musik gereja.

- Memiliki jaringan kerja sama dengan komponis-komponis gereja lokal dalam menjalankan lokakarya inkulturasi musik liturgi.

Kelemahan:

- Regenerasi yang belum memadai sehingga masih bergantung pada figur pendiri.

- Belum adanya sosialisasi yang menyeluruh ke pelosok gereja-gereja yang ada di nusantara.

- Kegiatan lokakarya belum menjangkau semua budaya yang ada di nusantara.

- Keterbatasan tenaga pengelola baik dari segi kuantitas maupun kualitas.

Eksternal

Peluang:

- Adanya dukungan dari KWI dalam mengembangkan nyanyian inkulturasi untuk memperkaya musik liturgi.

- Terdapat komponis-komponis lokal yang paham dengan kultur setempat yang terus bekerja sama dalam mengaransemen musik gereja.

- Gereja nusantara sudah mulai menggunakan nyanyian inkulturasi sebagai nyanyian wajib dalam liturgi.

- Terdapat banyak lagu daerah di wilayah nusantara yang akan digunakan dalam proses inkulturasi.

Ancaman:

- Terdapat nyanyian-nyanyian bergaya profan dalam gereja Katolik yang meredam lagu-lagu inkulturasi.

- Adanya anggapan musik inkulturasi terlalu kuno.

- Terdapat banyak komunitas paduan suara yang membawakan nyanyian dari luar atau yang diaransemen sendiri.

\section{Tahap Masukan}

Melalui penyebaran kuesioner yang diberikan kepada beberapa responden, diperoleh data yang disajikan melalui beberapa tabel. Analisis internal dilakukan untuk mengetahui kekuatan dan kelemahan yang dimiliki oleh Pusat Musik Liturgi. Analisis ini akan disajikan dalam matriks Internal Factor Evaluation (IFE) dan analisis eksternal dilakukan untuk 
mengidentifikasi peluang dan ancaman yang dihadapi oleh PML. Secara ringkas disajikan dalam matriks External Factor Evaluation (EFE).

Tabel Penilaian bobot faktor Internal Kekuatan \& Kelemahan

\begin{tabular}{|c|c|c|c|c|c|}
\hline $\begin{array}{c}\text { FAKTOR } \\
\text { INTERNAL }\end{array}$ & $\begin{array}{c}\text { Karl } \\
\text { Edmud } \\
\text { Prier. Sj }\end{array}$ & $\begin{array}{c}\text { Paul } \\
\text { Widyawan }\end{array}$ & $\begin{array}{c}\text { Yohanes } \\
\text { Wahyudi }\end{array}$ & $\begin{array}{c}\text { Benyamin } \\
\text { Regi }\end{array}$ & $\begin{array}{c}\text { RATA- } \\
\text { RATA }\end{array}$ \\
\hline A & $\mathbf{0 , 0 5}$ & $\mathbf{0 , 0 9}$ & $\mathbf{0 , 1 4}$ & $\mathbf{0 , 1 0}$ & $\mathbf{0 , 0 9 5}$ \\
\hline B & $\mathbf{0 , 0 5}$ & $\mathbf{0 , 0 8}$ & $\mathbf{0 , 1 4}$ & $\mathbf{0 , 1 3}$ & $\mathbf{0 , 0 9 2}$ \\
\hline C & $\mathbf{0 , 0 8}$ & $\mathbf{0 , 1 0}$ & $\mathbf{0 , 0 7}$ & $\mathbf{0 , 1 3}$ & $\mathbf{0 , 0 9 5}$ \\
\hline D & $\mathbf{0 , 0 5}$ & $\mathbf{0 , 0 9}$ & $\mathbf{0 , 0 7}$ & $\mathbf{0 , 1 3}$ & $\mathbf{0 , 0 8 5}$ \\
\hline E & $\mathbf{0 , 1 2}$ & $\mathbf{0 , 1 2}$ & $\mathbf{0 , 1 4}$ & $\mathbf{0 , 1 3}$ & $\mathbf{0 , 1 2 7}$ \\
\hline F & $\mathbf{0 , 1 2}$ & $\mathbf{0 , 1 3}$ & $\mathbf{0 , 1 3}$ & $\mathbf{0 , 1 3}$ & $\mathbf{0 , 1 2 7}$ \\
\hline G & $\mathbf{0 , 1 2}$ & $\mathbf{0 , 1 4}$ & $\mathbf{0 , 0 9}$ & $\mathbf{0 , 0 7}$ & $\mathbf{0 , 1 0 5}$ \\
\hline H & $\mathbf{0 , 1 2}$ & $\mathbf{0 , 1 3}$ & $\mathbf{0 , 0 9}$ & $\mathbf{0 , 1 0}$ & $\mathbf{0 , 1 1 0}$ \\
\hline I & $\mathbf{0 - 0 8}$ & $\mathbf{0 - 0 4}$ & $\mathbf{0 , 1 3}$ & $\mathbf{0 , 1 0}$ & $\mathbf{0 , 1 1 2}$ \\
\hline & \multicolumn{7}{|l}{ TOTAL } & & $\mathbf{1 , 0 0 0}$ \\
\hline
\end{tabular}

Pada tabel di atas menunjukkan bahwa, faktor internal pengelolaan musik liturgi pada PMLYogyakarta yang memiliki bobot tertinggi adalah memiliki jaringan kerja sama dengan komponis-komponis gereja lokal dalam menjalankan lokakarya inkulturasi musik liturgi dan regenerasi yang belum memadai sehingga masih bergantung pada figur pendiri.

Tabel Penilaian bobot faktor Eksternal Peluang dan Ancaman

\begin{tabular}{|c|c|c|c|c|c|}
\hline $\begin{array}{c}\text { FAKTOR } \\
\text { EXSTERNAL }\end{array}$ & $\begin{array}{c}\text { Karl } \\
\text { Edmud } \\
\text { Prier. Sj }\end{array}$ & $\begin{array}{c}\text { Paul } \\
\text { Widyawan }\end{array}$ & $\begin{array}{c}\text { Yohanes } \\
\text { Wahyudi }\end{array}$ & $\begin{array}{c}\text { Benyamin } \\
\text { Regi }\end{array}$ & $\begin{array}{c}\text { RATA- } \\
\text { RATA }\end{array}$ \\
\hline A & $\mathbf{0 , 1 8}$ & $\mathbf{0 , 1 2}$ & $\mathbf{0 , 2 0}$ & $\mathbf{0 , 1 5}$ & $\mathbf{0 , 1 8 5}$ \\
\hline B & $\mathbf{0 , 1 3}$ & $\mathbf{0 , 1 1}$ & $\mathbf{0 , 1 3}$ & $\mathbf{0 , 1 1}$ & $\mathbf{0 , 1 2 0}$ \\
\hline C & $\mathbf{0 , 1 3}$ & $\mathbf{0 , 1 5}$ & $\mathbf{0 , 1 1}$ & $\mathbf{0 , 1 1}$ & $\mathbf{0 , 1 2 5}$ \\
\hline D & $\mathbf{0 , 1 4}$ & $\mathbf{0 , 1 6}$ & $\mathbf{0 , 1 8}$ & $\mathbf{0 , 2 0}$ & $\mathbf{0 , 1 7 0}$ \\
\hline E & $\mathbf{0 , 1 3}$ & $\mathbf{0 , 1 7}$ & $\mathbf{0 , 1 4}$ & $\mathbf{0 , 1 1}$ & $\mathbf{0 , 1 3 7}$ \\
\hline F & $\mathbf{0 , 1 6}$ & $\mathbf{0 , 1 3}$ & $\mathbf{0 , 1 4}$ & $\mathbf{0 , 1 7}$ & $\mathbf{0 , 1 5 0}$ \\
\hline G & $\mathbf{0 , 1 7}$ & $\mathbf{0 , 1 5}$ & $\mathbf{0 , 1 1}$ & $\mathbf{0 , 1 7}$ & $\mathbf{0 , 1 5 7}$ \\
\hline & \multicolumn{7}{|c}{ TOTAL RATA-RATA } & 1.000 \\
\hline
\end{tabular}

Pada tabel di atas menunjukkan bahwa, faktor eksternal pengelolaan inkulturasi musik liturgi pada PML Yogyakarta yang memiliki bobot tertinggi adalah adanya dukungan dari KWI dalam mengembangkan nyanyian inkulturasi untuk memperkaya musik liturgi. 


\section{Tahap Pencocokan}

Hasil perhitungan di atas, diperoleh hasil IFE sebesar 2,069 dan EFE sebesar 2.018. Angka tersebut selanjutnya dapat menggambarkan posisi Pusat Musik Liturgi dalam pengelolaan Inkulturasi musik liturgi melalui Matriks IE.

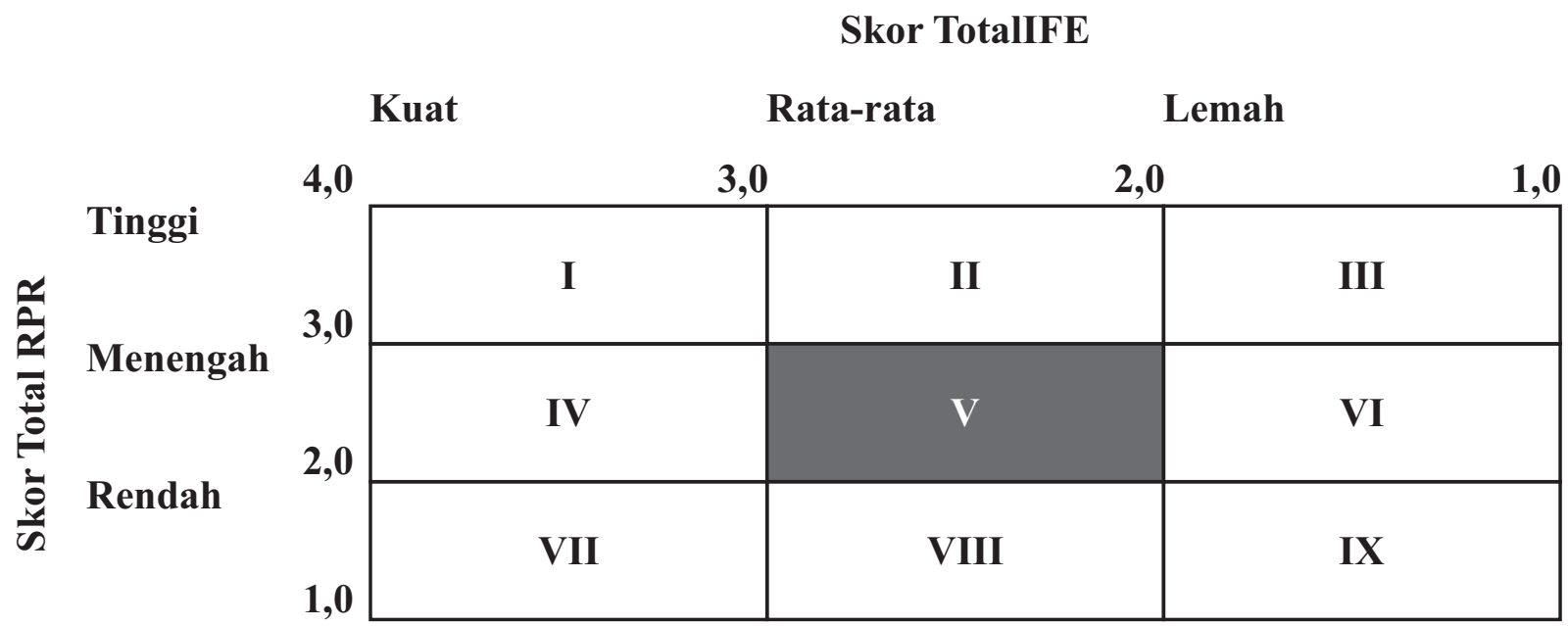

Berdasarkan hasil matriks IFE dan EFE, maka dapat dilihat pada tabel di atas bahwa posisi pengelola Pusat Musik Liturgi dalam pengelolaan Inkulturasi musik liturgi melalui Matriks IE menunjukan Hold and Maintain (pertahankan dan pelihara) karena berada pada posisi V. Oleh karena itu, strategi yang tepat dilakukan oleh pengelola adalah menjaga dan mempertahankan posisi pada indikator internal huruf E, yaitu memiliki jaringan kerja sama dengan komponis-komponis gereja lokal dalam menjalankan lokakarya inkulturasi musik liturgy yang selama ini sudah diraih. Kebijakan yang umum dari strategi ini adalah dengan melakukan penetrasi pasar dan mengembangkan produk. Artinya pengelola lembaga harus mempertahankan posisinya dengan terus mengembangkan karya-karya seperti menulis dan mendistribusikan buku, compact disk (CD) nyanyian Madah Bakti. Pengembangan produk dapat dilakukan dengan memberdayakan indikator peluang huruf $\mathrm{D} 0,340$ yang menunjukkan banyaknya lagu daerah di wilayah nusantara yang dapat digunakan dalam proses inkulturasi. Selain itu, melakukan penetrasi pasar yang lebih potensial dengan memberdayakan indikator terkuat pada kekuatan yaitu huruf E dengan bobot skor 0,254 dan indikator peluang pada huruf D dengan bobot skor 0,340. Jaringan kerja sama yang dimiliki dapat diberdayakan untuk memperkuat (penataran, pelatihan, lokakarya) keberlanjutan musik liturgi dalam mendistribusikan karya musik liturgi. Selain itu, PML dapat mengembangkan karya-karya musik liturgi dengan mengaransemen musik dan lagu daerah yang ada di wilayah nusantara dengan tetap menjaga konsistensi dan kualitas produk.

Tahap selanjutnya juga dilakukan pencocokkan melalui KUADRAN ANALISIS SWOT, untuk itu diperlukan bobot skor Faktor Internal dan bobot skor Faktor Eksternal. Bobot skor Faktor Internal diperoleh dari bobot skor Kekuatan dikurangi Kelemahan, sedangkan bobot skor Faktor Eksternal diperoleh dari Peluang dikurangi Ancaman.

Melalui perhitungan tersebut, maka diperoleh koordinat untuk Kuadran Analisis SWOT yaitu (-0,173; 0,376). Selanjutnya koordinat tersebut dapat digambarkan melalui Kuadran Analisis SWOT dalam pengelolaan Inkulturasi musik liturgi. 


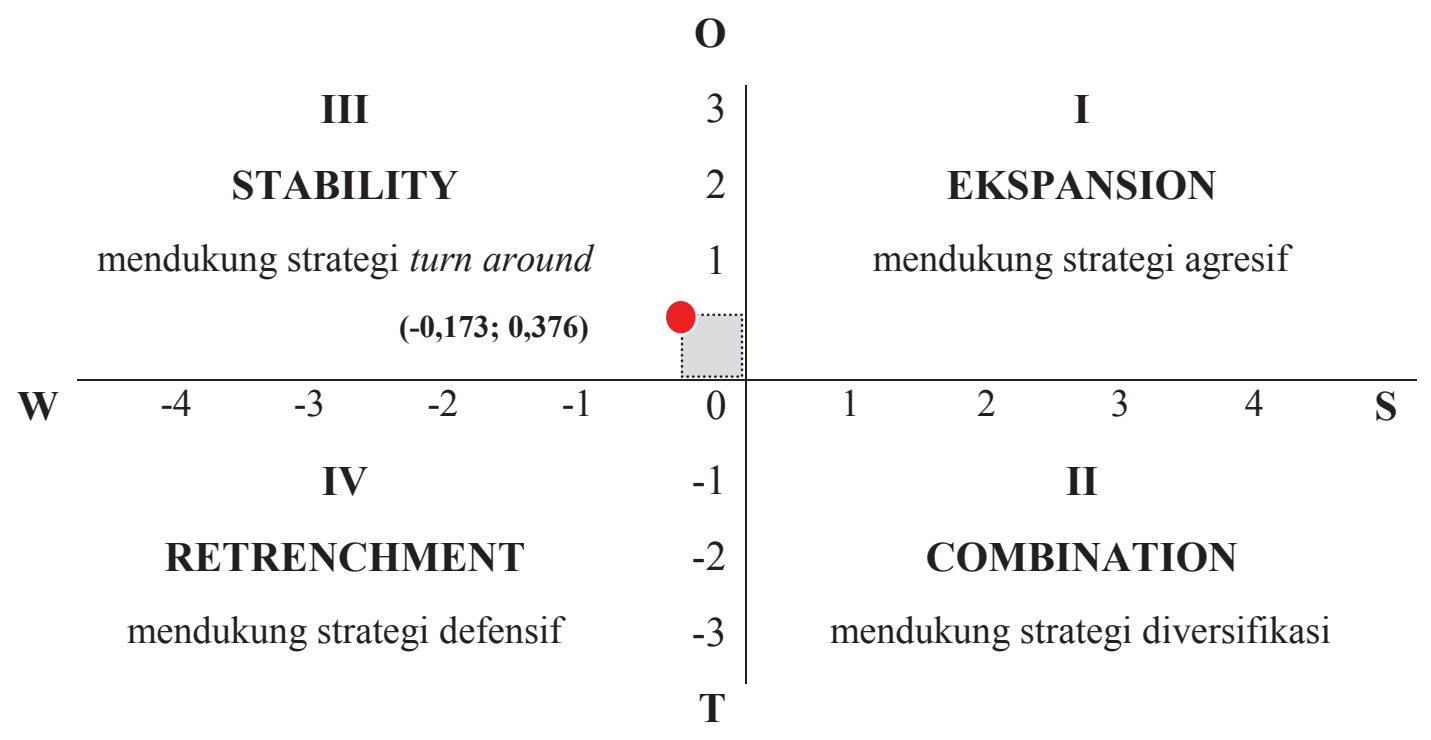

\section{Koordinat kuadran analisis SWOT}

Kuadran analisis SWOT pengelolaan Inkulturasi musik liturgi menunjukkan posisinya berada pada kuadran III yaitu suatu lembaga menghadapi peluang pasar yang sangat besar, tetapi di lain pihak menghadapi beberapa kendala atau kelemahan internal, seperti regenerasi yang belum memadai sehingga masih bergantung pada figur pendiri, keterbatasan tenaga pengelola baik dari segi kuantitas maupun kualitas, dan kegiatan lokakarya belum menjangkau semua kultur atau budaya yang ada di nusantara. Untuk mendukung strategi ini dilakukan (turn around) sehingga dapat meminimalkan masalah internal organisasi PML dengan memberdayakan pengelola yang profesional pada indikator internal huruf $\mathrm{C}$ untuk menghadapi dan memanfaatkan peluang secara optimal.

Selain itu, adanya dukungan dari KWI dalam mengembangkan nyanyian inkulturasi dengan bobot skor 0,277 mampu meminimalisasikan kendala-kendala yang dihadapi PML. Dengan demikian PML bisa melakukan pengembangan produk dengan mengaransemen lagulagu daerah (lihat indikator peluang huruf D) agar musik liturgi tidak kalah eksis dengan nyanyian yang bergaya profane di gereja katolik.

\section{Tahap Keputusan}

Strategi Menurut Matriks IE

Keadaan Pusat Musil Liturgi di Yogyakarta melalui Matriks IE menunjukan Hold and Maintain (pertahankan dan pelihara) karena berada pada posisi V. Strategi umum yang dipakai adalah menjaga dan mempertahankan posisi pada indikator internal huruf E, yaitu memiliki jaringan kerja sama dengan komponis-komponis gereja lokal dalam menjalankan lokakarya inkulturasi musik liturgi yang selama ini sudah diraih.

Lembaga mempertahankan posisinya dengan terus mengembangkan karya-karya seperti menulis dan mendistri busikan buku, compact disk (CD) nyanyian berupa Madah Bakti. Pengembangan produk dapat dilakukan dengan memberdayakan indikator peluang huruf $\mathrm{D}$ dengan bobot skor 0,340 yang menunjukan banyaknya lagu daerah diwilayah nusantara yang dapat digunakan dalam proses inkulturasi. Selain itu, PML mampu mengembangkan karya- 
karya musik liturgi dengan mengaransement musik dan lagu daerah yang ada di wilayah nusantara dengan tetap menjaga konsistensi dan kualitas produk. Aransement dilakukan untuk menunjukan kreativitas dan kekayaan musikalitas musik liturgi dalam mengatasi ancaman terkait adanya anggapan musik inkulturasi terlalu kuno.

Strategi pada Kuadran Analisis SWOT Kuadran analisis SWOT pengelolaan Inkulturasi musik liturgi menunjukan posisinya berada pada kuadran III yaitu suatu lembaga menghadapi peluang pasar yang sangat besar, tetapi di lain pihak menghadapi beberapa kendala dalam internal seperti regenerasi yang belum memadai sehingga masi bergantung pada figur pendiri, keterbatasan tenaga pengelola baik dari segi kuantitas maupun kualitas, dan kegiatan lokakarya belum menjangkau semua budaya yang ada di nusantara. Dengan demikian fokus strategi ini yaitu meminimalkan masalah internal organisasi tersebut sehingga dapat merebut pasar yang lebih baik. Masalah yang ada (pada indikator kelemahan) pada PML dapat diminimalisir dengan pemberdayaan peluang-peluang yang sudah ada seperti kerja sama dengan KWI dalam menghadirkan figur-figur berpengaruh di PML dan kemampuan secara mandiri dalam berkarya (pada indikator kekuatan huruf B) menjadi modal penting untuk dimanfaatkan, sehingga strategi yang tepat adalah melatih generasi yang unggul, dengan melakukan kegiatan lokakarya, mensosialisasikan musik inkulturasi secara intensif dan metodologis.

\section{Hasil analisis matriks SWOT}

Dari hasil yang telah dianalisis maka dapat diberikan beberapa alternatif strategi yaitu:

\begin{tabular}{|l|l|}
\hline SO: & $\begin{array}{l}\text { 1. Menambah karya musik atau nyanyian nusantara dalam inkulturasi musik } \\
\text { liturgi. }\end{array}$ \\
& $\begin{array}{l}\text { 2. Menberikan penataran dalam setiap tahun di gereja-gereja katolik yang } \\
\text { belum memahami tentang musik inkulturasi. }\end{array}$ \\
3. Memberikan ilmu pengetahuan dan penerjemah kepada pengelola sehingga \\
cukup memadai.
\end{tabular}

Posisi Pusat Musik Liturgi dalam Pengelolaan Inkulturasi Musik Liturgi melalui Matriks IE menunjukkan Hold and Maintaind (pertahankan dan pelihara), sehingga strategi umum yang dipakai adalah penetrasi pasar dan pengembangan produk. Posisi tersebut mengarah pada strategi: 1. Menambah karya musik atau nyanyian nusantara dalam inkulturasi musik 
liturgi dan memberikan penataran dalam setiap tahun di gereja-gereja katolik yang belum memahami tentang musik inkulturasi; 2. Pengembangan produk: Mensosialisasikan musik inkulturasi dalam kegiatan-kegiatan gereja dan memberikan ilmu pengetahuan dan penerjemah kepada pengelola sehingga cukup memadai.

\section{Pembahasan}

Analisis matrik IE pada posisi $\mathrm{V}$ hold and maintaind (pertahankan dan pelihara) mengisyaratkan suatu strategi menjaga dan mempertahankan posisi yang sudah diraih, seperti faktor-faktor yang dimuat pada setiap indikator kekuatan dan peluang. Faktor-faktor yang diuraikan pada setiap indikator memiliki perbedaan, dari faktor internal kekuatan dan kelemahan dalam perhitungan yang tertinggi dengan bobot skor 0,254 ialah memiliki jaringan kerja sama dengan komponis-komponis gereja lokal dalam menjalankan lokakarya inkulturasi musik liturgi dan regenerasi yang belum memadai sehingga masih bergantung pada figur pendiri. Pada faktor eksternal bobot skor tertinggi terdapat pada faktor "Adanya dukungan dari KWI dalam mengembangkan nyanyian inkulturasi untuk memperkaya musik liturgi” dengan skor 0,277. Di sisi lain PML memiliki kelemahan dengan bobok skor 0,342 pada faktor internal huruf F. Bobot skor pada faktor F paling tinggi dibandingkan faktorfaktor yang lain. Oleh sebab itu penting adanya pemberdayaan kemampuan pengelolaan yang propesional dalam meregenerasi anggota dan figur-figur berpengaruh di dalam lembaga PML. Selain itu jaringan-jaringan kerja PML dengan komponis gereja lokal akan memberikan dampak yang signifikan terhadap realisasi program lokakarya inkulturasi musik liturgi.

Dari data yang telah dianalisis pada kuadran SWOT, terdapat pemberian peringkat dari masing-masing variabel, dimana dalam penjumlahan didapatkan hasil dari perhitungan melalui kuadran analisi IFE sebesar 2,069 dan EFE sebesar 2.018.

Angka tersebut selanjutnya dapat digambarkan posisi Pusat Musik Liturgi dalam pengelolaan Inkulturasi musik liturgi melalui Matriks IE yang artinya Hold and Maintain (pertahankan dan pelihara) karena berada pada posisi V. Oleh karena itu strategi yang terbaik sebaiknya dilakukan oleh pengelola adalah menjaga dan mempertahankan posisi yang selama ini sudah diraih. Posisi terpenting adala indikator peluang huruf D yang secara srategis dapat memperkaya kreativitas penciptaan musik liturgi dengan pemberdaya musik-musik nusantara.

Setelah mendapatkan hasil tersebut muncullah koordinat untuk Kuadran Analisis SWOT yaitu (-0,173; 0,376) yang menunjukkan bahwa pengelolaan inkulturasi musik liturgi berada pada posisinya kuadran III yaitu suatu organisasi menghadapi peluang pasar yang sangat besar, tetapi di lain pihak menghadapi beberapa kendala/kelemahan internal. Fokus strategi ini yaitu meminimalkan masalah internal lembaga tersebut sehingga dapat merebut pasar yang lebih baik, sehingga strategi yang baik adalah melatih generasi yang unggul sehingga musik inkulturasi tetap terjaga, mensosialisasikan musik inkulturasi dalam kegiatan-kegiatan gereja, dan perlu adanya kegiatan lokakarya yang lebih diperhatikan lagi kaena sulitnya penerjemaan syair dan motif lagu yang menjadi sumber. 


\section{Kesimpulan}

Berdasarkan uraian dalam bab-bab sebelumnya, maka dapat ditarik kesimpulan sebagai berikut.

Strategi pengelolaan Inkulturasi Musik Liturgi yang digunakan Pusat Musik Liturgi yang di analisis dari matriks IE posisi yang telah didapat yaitu pada posisi V yang dimana Pengelolaan Inkulturasi Musik Liturgi pada Pusat Musik Liturgi ini menunjukkan Hold and Maintaind yang artinya (pertahankan dan pelihara). Oleh karena itu strategi yang tepat untuk dilakukan oleh pengelola adalah menjaga dan mempertahankan posisi yang selama ini sudah diraih. Pengelola lembaga mempertahankan posisinya dengan terus mengembangkan karya dengan mengarasemen musik-musik nusantara dan memberdayakan jaringan-jaringan dengan para komponis gereja lokal dalam merealisasikan program lokakarya.

Dari matriks IE, tahap selanjutnya juga dilakukan pencocokkan melalui Kuadran Analisis SWOT, untuk itu diperlukan bobot skor Faktor Internal dan bobot skor Faktor Eksternal. Bobot skor Faktor Internal diperoleh dari bobot skor Kekuatan dikurangi Kelemahan, sedangkan bobot skor Faktor Eksternal diperoleh dari Peluang dikurangi Ancaman dan melalui perhitungan tersebut, maka diperoleh koordinat untuk Kuadran Analisis SWOT yaitu (-0,173; 0,376). Kuadran analisis SWOT pengelolaan pusat musik liturgi menunjukkan posisinya berada pada kuadran III yaitu suatu lembaga menghadapi peluang pasar yang sangat besar, tetapi di lain pihak menghadapi beberapa kendala atau kelemahan internal. Fokus strategi ini yaitu meminimalkan masalah internal lembaga tersebut sehingga dapat merebut pasar yang lebih baik (turn around).

\section{Kepustakaan}

Budi, Aloys. 2010. Merayakan Iman dalam Ibadah dan Doa Bersama. Medan: Penerbit Bina Media.

Chulsum, Umi dan Novia Windy. 2016. "Kamus Besar Bahasa Indonesia” Jakarta: Kashiko.

F, David. 2016. Manajemen Strategis Edisi 10. Jakarta: Salemba Empat.

SJ, R. Hardawiryana. 1993. Dokumen Konsili Vatikan II (terjemahan). Jakarta: Obor.

Dr. Huub J.W.M. Boelaars, OFM Cap. 2015. Indonesianisasi: Dari Gereja Katolik di Indonesia menjadi Gereja Katolik Indonesia, Kanisius. Yogyakarta: Emha. Pusat Musik Liturgi dalam HIDUP No.10 1983, 8.

Herliana, Emmilia Tricia. 2012. Analogi Musik melalui Proses Transformasi pada Simulasi Memperluas Gereja Katedral Medan.

Hardjana, Suka. 2004. Esai dan Kritik Musik. Yogyakarta: Galang Press.

Kotler, Philip. 2010. Prinsip-Prinsip Pemasaran Edisi 9 (terjemahan). Jakarta: Erlangga. 2007. Marketing Management (terjemahan). Jakarta: Erlangga.

_. 2008. Manajemen Pemasaran Edisi 12 (terjemahan). Jakarta: Erlangga.

Kusno, Suhendro. 1990. Arti dan Makna Liturgi. Majalah Ekawarta: Forum Komunikasi KWI, edisi Juni, no. 3/X/1990.

Leiper. 2008. Manajemen Pemasaran dan Pemasaran Jasa. Bandung: CV. Alfabeta.

Lincoln dan Guba, Tjiptono. 2007. Strategi Pengelolaan. Yogyakarta: Andi Offset. 
Manik, Chirsmes Elisabet. 2013. Inkulturasi Musik Batak Toba dalam Ordinarium pada Perayaan Misa Gereja Katolik Santo Antonius Hayam Wuruk Medan: Analisis Struktur Musik Dan Tekstual.

Murgiyanto, Sal. 1985. Managemen Pertunjukan. Jakarta: Departemen Pendidikan dan Kebudayaan. 